\title{
A Simplified Control Strategy for an Enhanced Performance of Six Level Dual Inverter Fed Induction Motor Drive
}

\author{
Usha Nadimpalli, P.V. Prasad, Kolli Ramesh Reddy
}

\begin{abstract}
Induction motor drives are employed in many of the industrial applications. The drives output depends on the inverter. Multilevel inverters are generally used in the induction motor drives but the dual inverter fed induction motor drive found more advantageous than the multilevel inverters. The performance of the Induction motor drive with open end winding for various levels of output voltage is presented in this paper. The inverter configuration implemented produces three-level, fourlevel, five-level and six-level in the output voltage waveform. The voltage and current harmonic distortion decreases as the number of levels are increased. The performance of the motor drive with the proposed inverter topology was found effective for sixth level. The simulation analysis of Induction motor drive with dual inverter is carried out in MATLAB-Simulink environment.

Keywords: Open end winding Induction motor drive, Dual Inverter, PWM, SPWM,SVPWM,THD.
\end{abstract}

\section{I.INTRODUCTION}

Most of industrial drive applications employ Voltage source Inverter for their effective control. When a single inverter is used, output voltage contains harmonics which have effect on the induction motor performance and also leads to the phase currents ripple. So there is a need for improving the performance of inverters[1]. The essential characteristics of inverters are less harmonics in the output, low switching losses and less common mode voltage. In order to obtain sinusoidal voltage without harmonics from inverter various methods are employed such as PWM Technique with High frequency, Low Frequency and Dual inverter[2]. In this work, a dual inverter is used to drive the induction motor. This dual inverter circuit utilises less number of diodes, capacitors and DC sources therefore minimising overall cost. In Dual fed induction motor stator windings of motor are opened and fed from inverters on either side. Isolated DC supply are provided to both the inverters and AC obtained from inverter is given to induction motor stator. If the DC input supply given to both the inverters is same then such configuration is called symmetrical dual inverter fed open end winding Induction motor drive and if DC input is different for both the inverters then it is called as Asymmetrical dual inverter fed open end winding induction motor drive.

Revised Manuscript Received on October 30, 2019.

* Correspondence Author

Usha Nadimpalli*, EEE Department, JNTU Hyderabad, India. Email: usha0578@gmail.com.

P.V. Prasad ${ }^{2}$ EEE Department, CBIT, Gandipet, Hyderabad, India. Email: pvp_reddy@yahoo.co.uk

Kolli Ramesh Reddy ${ }^{3}$ EEE Department, GNITS, Shaikpet, Hyderabad,India. Email: kollirameshreddy@yahoo.com

(C) The Authors. Published by Blue Eyes Intelligence Engineering and Sciences Publication (BEIESP). This is an open access article under the CC BY-NC-ND license (http://creativecommons.org/licenses/by-nc-nd/4.0/)
As the levels in the inverter output voltage increased, the harmonic content in the output of inverter can be reduced. The output voltage levels are increased by adjusting the DC input voltages leading to reduction in cost and complexity in the circuit[3]. The increase in levels also increases the complexity of circuit but with this proposed circuit configuration, one more bridge circuit is included for obtaining the fifth and sixth levels of output voltage. This control strategy yields less switching losses along with reduced current ripples.

In this proposed power circuit configuration three isolated DC supplies are essential to produce higher levels in the inverter voltage. The common issue in the induction motor drive with dual inverter is zero sequence currents which can be overcome by choosing a carrier based PWM method[4].

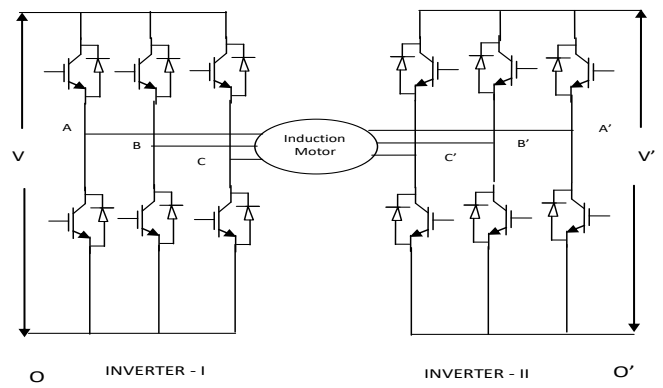

Figure 1 Dual inverter fed open end stator winding induction motor drive

A simplified circuit with two level inverters, Inverter I and II are used as shown in the Fig.1. The difference of output voltage of Inverter-I and Inverter-II is effective voltage which is fed to the induction motor stator. A symmetric dual inverter with input DC voltage of $\frac{2 V_{d c}}{3}$ is used to produce three levels of voltage. An asymmetric dual inverter is used to generate four levels voltage with a DC input voltages of $\frac{2 V_{d c}}{3}$ and $\frac{V_{d c}}{3}$. To generate five

levels one more bridge circuit is included in the Inverter-I by making 6 switches as each group with input DC voltage as $\frac{V_{d c}}{4}$ and the input voltage to Inverter-II is taken as $\frac{V_{d c}}{2}$ as shown in Figure 2. Same circuit configuration is used to generate the six levels of DC voltage input as $\frac{2 V_{d c}}{6}$ and $\frac{V_{d c}}{6}$. 


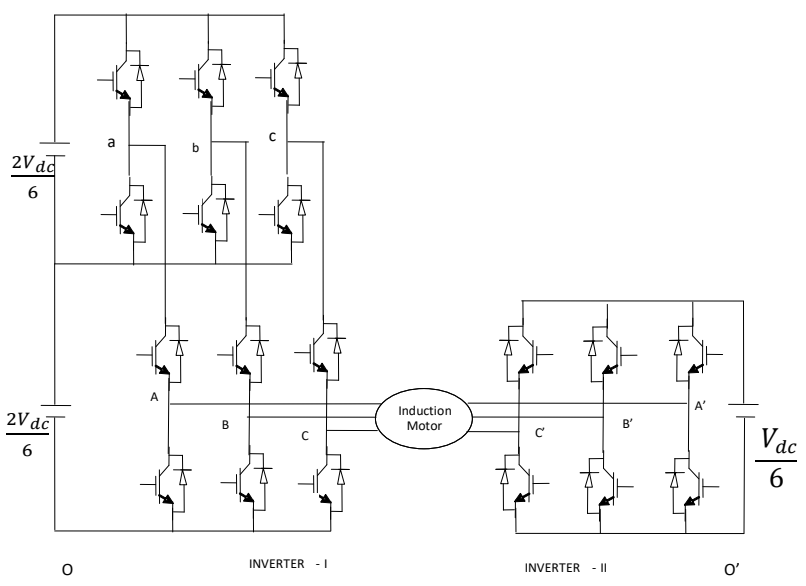

Fig 2 Modified Dual inverter configuration

Table I Different levels of Voltage in Phase-A Winding when Inverter I \& II are switched independently.

\begin{tabular}{|c|c|c|l|}
\hline $\begin{array}{l}\text { Inverter I } \\
\text { Pole Voltage } \\
\mathrm{V}_{\mathrm{A} 1}\end{array}$ & $\begin{array}{l}\text { Inverter II } \\
\text { Pole Voltage } \\
\mathrm{V}_{\mathrm{A} 2}\end{array}$ & $\begin{array}{l}\text { Effective } \\
\text { Voltage, } \mathrm{V}_{\mathrm{A}}=\mathrm{V} \\
{ }_{\mathrm{A} 1}-\mathrm{V}_{\mathrm{A} 2}\end{array}$ & Level \\
\hline 0 & $\frac{V_{d c}}{6}$ & $-\frac{V_{d c}}{6}$ & Level I \\
\hline 0 & 0 & 0 & Level II \\
\hline$\frac{2 V_{d c}}{6}$ & $\frac{V_{d c}}{6}$ & $\frac{V_{d c}}{6}$ & Level III \\
\hline$\frac{2 V_{d c}}{6}$ & 0 & $\frac{2 V_{d c}}{6}$ & Level IV \\
\hline$\frac{4 V_{d c}}{6}$ & $\frac{V_{d c}}{6}$ & $\frac{3 V_{d c}}{6}$ & Level V \\
\hline$\frac{4 V_{d c}}{6}$ & 0 & $\frac{4 V_{d c}}{6}$ & Level VI \\
\hline
\end{tabular}

\section{II.SIMPLIFIED PWM METHOD}

The block diagram of the drive system is shown in the Fig. 3. Drive system consists of DC source and inverters. Three phase Inverters are employed to get controlled output to drive the three phase induction motor at required conditions, which is obtained through a controller.

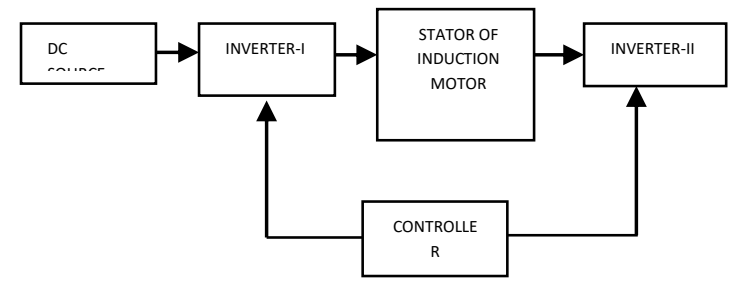

Figure 3 Block Diagram of the Induction Motor Drive System

The voltage source inverter converts fixed DC to Variable AC. The DC voltage used is fixed and regulated. While on AC side output voltage is not sinusoidal, which contains harmonics. These harmonics results in increasing losses and pulsating torque at the induction motor side, while a sinusoidal output produces a steady state torque. Pulsating torque consists of both fundamental torque and harmonic torque. Hence these unwanted harmonics are to be mitigated. PWM techniques are used to mitigate these harmonics[5].
The comparison between the reference voltage and carrier waveform gives the on and off times for the switches in inverter. PWM is commonly used in many applications like audio amplifiers, converters, motor speed etc[6]. Of all the PWM techniques, sinusoidal PWM and space vector PWM are mostly used. SVPWM has low switching losses and high DC utilisation when compared with SPWM[7]. The SVPWM gives better harmonic compensation when compared to the SPWM. The maximum peak of output voltage fundamental component obtained with sine-triangle modulation is $15 \%$ lesser than with the space vector modulation [8].

While implementing the space vector pulse width modulation, calculation of dwell time is difficult but by using imaginary switching times, the complexity in dwell time calculation is reduced[9]. But it is still complex to calculate and time PWM is employed to improve the performance of inverter. Simplified PWM is a carrier based PWM, where a sinusoidal voltage is compared with the single triangular offset voltage for generation of the pulses in inverter.

\section{DUAL INVERTER CONTROL STRATEGIES}

The induction motor drive configuration with dual inverter as shown in the Fig. 1 fed from two unbalanced input voltages $\frac{2 V_{d c}}{3}$ and $\frac{V_{d c}}{3}$ to the two inverters. Since both the inverters are fed from unbalanced inputs, asymmetrical dual inverter drive configuration is used.

The leg voltages of the Inverter $\mathrm{I}$ are defined as $\mathrm{V}_{\mathrm{AO}}$, $\mathrm{V}_{\mathrm{BO}}$ and $\mathrm{V}_{\mathrm{CO}}$, measured between the corresponding leg and the input DC voltage. Similarly, the leg voltages of inverter II are defined as $\mathrm{V}_{\mathrm{A}^{\prime} \mathrm{O}}, \mathrm{V}_{\mathrm{B}^{\prime} \mathrm{O}^{\prime}}$ and $\mathrm{V}_{\mathrm{C}^{\prime} \mathrm{O}^{\prime}}$ measured between the corresponding leg and the input DC voltage of inverter II. V ${ }_{\mathrm{AA}}, \mathrm{V}_{\mathrm{BB}^{\prime}}$ and $\mathrm{V} \mathrm{CC}^{\prime}$ are the effective voltages of the drive configuration. The stator of induction motor is connected between the inverters, inverters- I produces the output voltage at $\frac{2 V_{d c}}{3}$ and 0 . Similarly inverter - II produces the output voltage $\frac{V_{d c}}{3}$ and 0 . If the top switches are $\mathrm{ON}$ in inverter I then output voltage produced is $\frac{2 V_{d c}}{3}$ and with bottom switches ON an output voltage of zero is obtained. Similarly, inverter II also produces a voltage of $\frac{V_{d c}}{3}$ and 0 . The effective voltages are obtained as

$$
\begin{aligned}
& \mathrm{V}_{\mathrm{AA}^{\prime}}=\mathrm{V}_{\mathrm{AO}}-\mathrm{V}_{\mathrm{A}^{\prime} \mathrm{O}^{\prime}} \\
& \mathrm{V}_{\mathrm{BB}^{\prime}}=\mathrm{V}_{\mathrm{BO}}-\mathrm{V}_{\mathrm{B}^{\prime} \mathrm{O}^{\prime}} \\
& \mathrm{V}_{\mathrm{CC}^{\prime}}=\mathrm{V}_{\mathrm{CO}}-\mathrm{V}_{\mathrm{C}^{\prime} \mathrm{O}^{\prime}}
\end{aligned}
$$

The effective voltage is the voltage fed to the stator of the motor and by taking the same voltages to both the inverters we get a three level of voltages as shown in Fig 4 

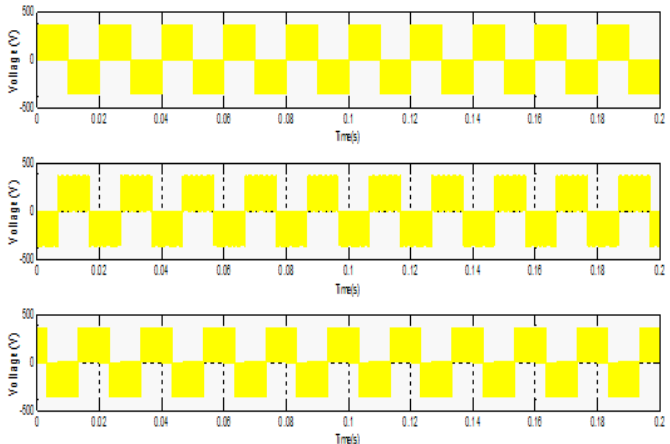

Figure 4 Effective Voltages with three levels of voltages

By considering an asymmetrical dual inverter, four level of voltages can be obtained as shown in the Fig 5
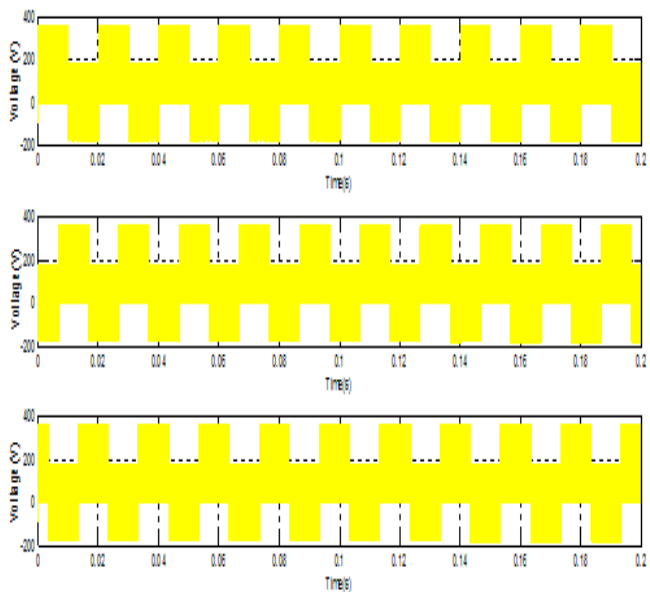

In order to obtain the five and six level of voltages in an asymmetric dual converter a bridge circuit is included in the inverter-I as shown in the Fig. 6 \&7.
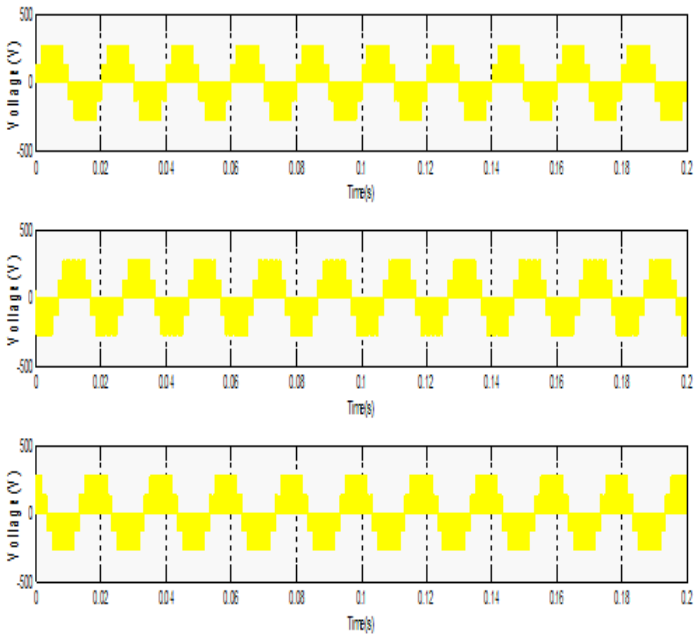

Figure 6 Effective Voltages with five levels of voltages

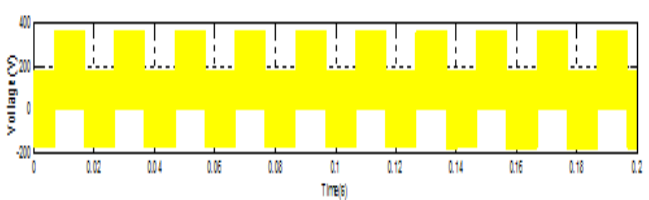

Figure 5 Effective Voltages with four levels of voltages.
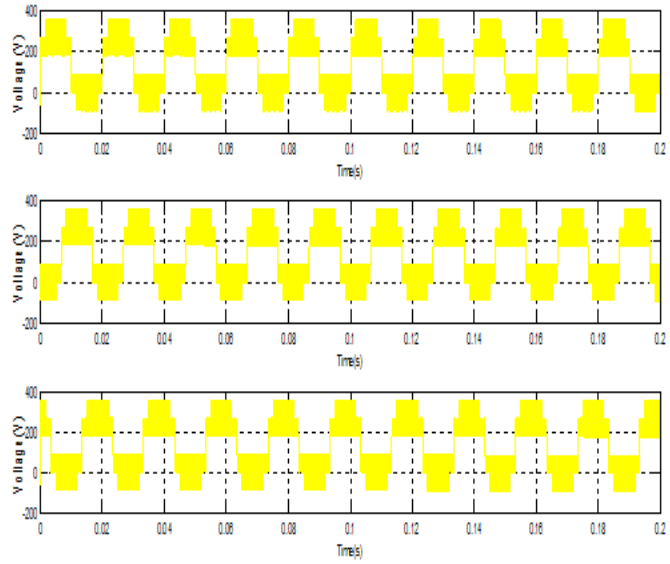

Figure 7 Effective Voltages with six levels of voltages

\section{RESULTS AND DISCUSSION}

The proposed control methodology is implemented in MATLAB. The simulation results at different levels of inverter output voltage are shown in Fig.8 to Fig.11. The phase current ripples with the three level of voltage is measured with fourier method and found that the total harmonic distortion to be at $71.91 \%$ and when four level voltages are obtained at the output of inverter, the total harmonic distortion was reduced to $54.59 \%$. For the fifth and sixth level voltages the THD obtained as $20.39 \%$ and $2.79 \%$ respectively. The different levels of voltage when fed to the motor drive the speed and torque response was quite satisfactory for sixth level in comparison to the lower levels as shown in the Fig $13 \& 14$.
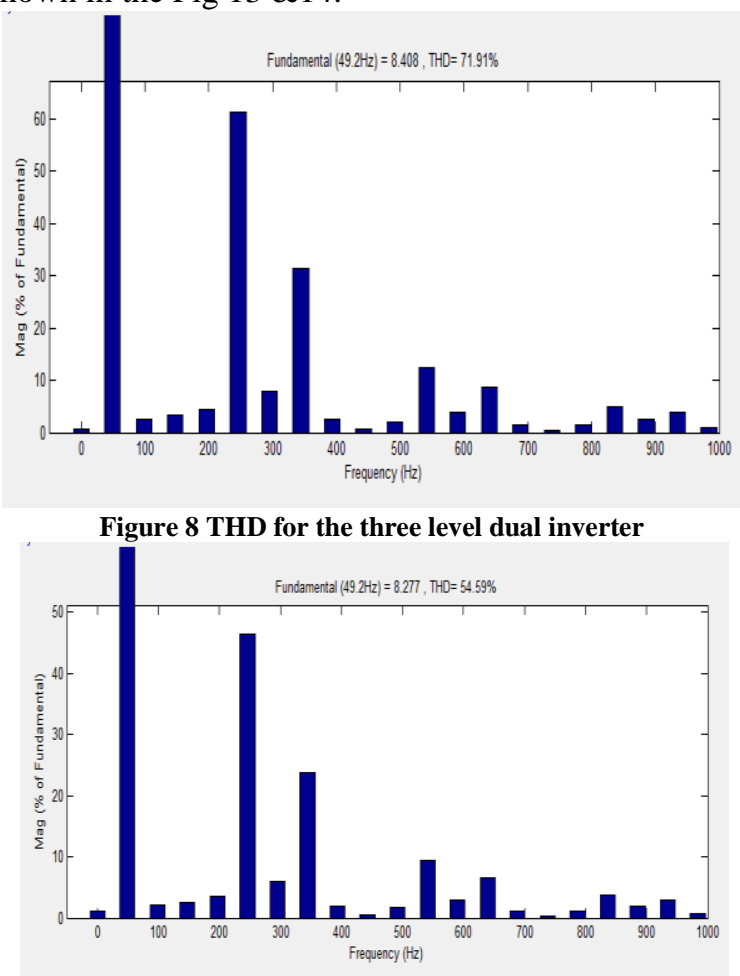

Figure 9 THD for the four level dual inverter

Published By: 


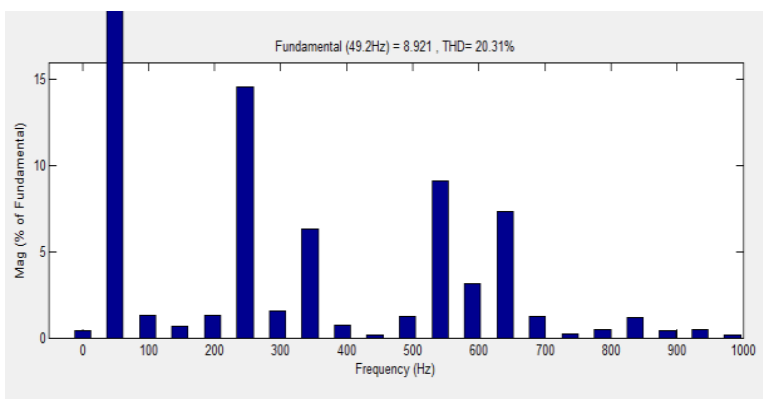

Figure 10 THD for the five level dual inverter

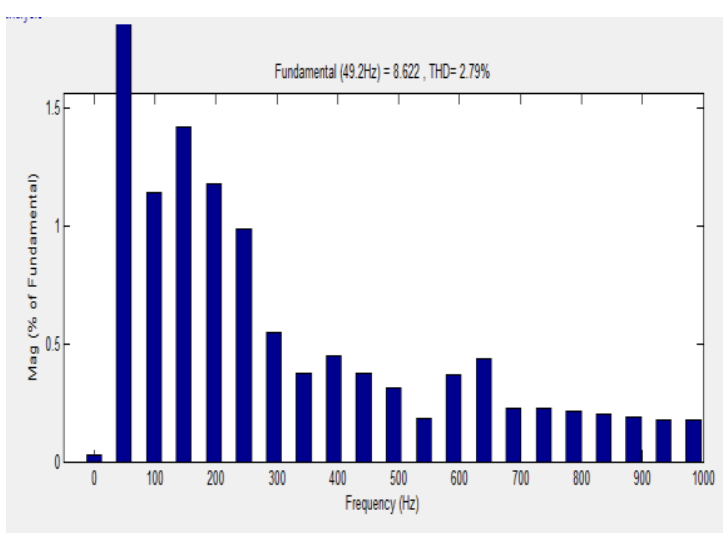

Figure 11 THD for the six level dual inverter

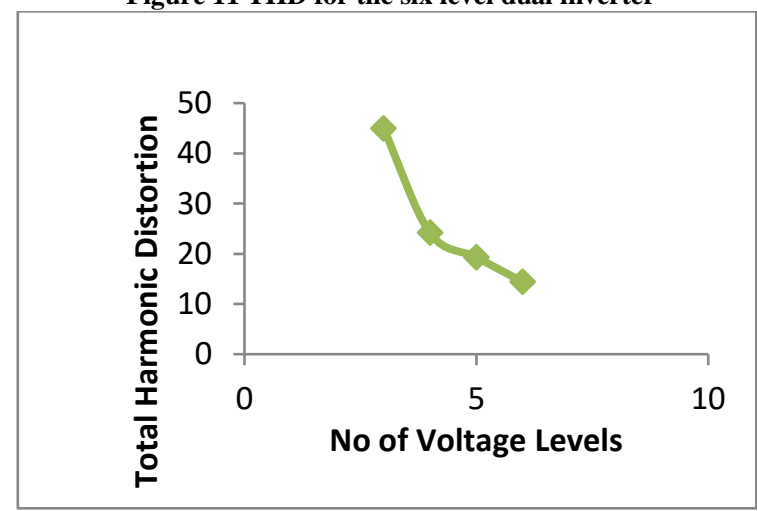
levels increased

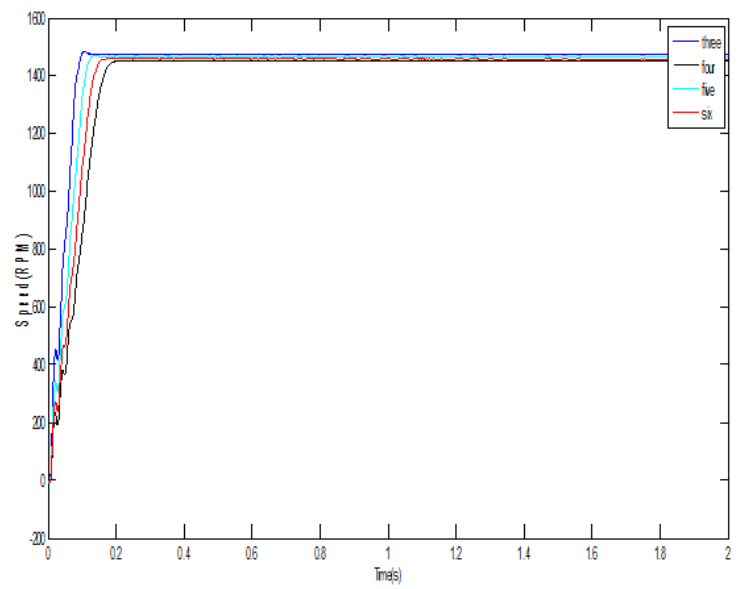

Figure 13 Speed curve for various levels of the dual inverter
Figure 12 Phase Voltage THD of the motor as the number of voltage

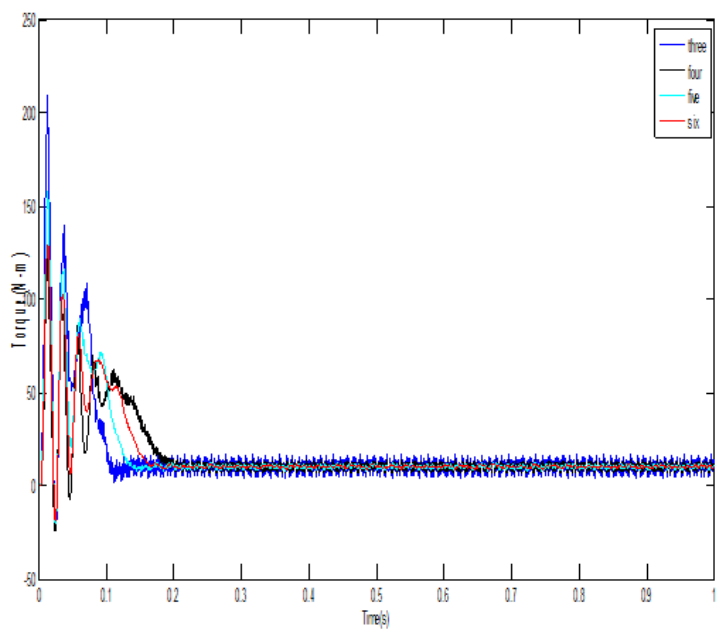

Figure 14 Torque curve for various levels of the dual inverter

\section{CONCLUSION}

The dual inverter configuration is less complex than the multilevel inverters since the proposed scheme uses less number of switching devices and Power supplies. As the number of switches are reduced, the generation of number of gating signals also reduces. For obtaining $\mathrm{N}$ levels in output voltage of inverter, N-1 Triangular carrier waves are to be generated whereas in the scheme of present work utilises only single triangular carrier wave with appropriate offset. The number of levels in the output of inverter are increased so that the voltage contains less harmonic content and minimising the ripples in the current. The levels in the voltage are increased by changing the input DC voltage. From the results it can be concluded that with the sixth level of inverter output voltage the current THD reduces to $2.79 \%$. The proposed method is cost effective as the number of sources and capacitors used are less and also single number of carrier wave is used for pulse generation. The simulation results give the effectiveness of the proposed method for better steady state and transient response of the torque and speed of the drive system.

\section{REFERENCES}

1. Harshavardhan Reddy. M, Ravindranath Reddy .B,Brahmananda Reddy.T, Suryakalavati.M, "Efficient control strategy for four level asymmetrical dual inverter fed induction motor drive", IEEE Power and Energy Systems Towards Sustainable Energy 2014.

2. Sandeep N Panchal, Vishal S Sheth, Akshay A Pandya, "Simulation analysis of SVPWM inverter fed induction motor drives", International Journal of Emerging Trends in Electrical and Electronics, Vol 2, Issue 4, April 2013.

3. Harshavardhan Reddy M., Suryakalavati M., Brahmananda Reddy.T, Ravindranath Reddy.B, "Generalised PWM technique for dual inverter fed induction motor drive", Acta Electrotechnica et Informatica, Vol. 14, No. 1, 2014.

4. Somasekhar.V.T, Gopakumar.K, Shivakumar E.G.“A space-vector modulation for a two level dual inverter fed open-end winding induction motor drive for the elimination of zero-sequence currents", Journal of European power electronics and drives, Vol. 12, 2002

5. Suresh L, Mahesh M, Janardhan M, Mahesh K, "Simulation of space vector pulse width modulation for voltage source inverter using Matlab/Simulink", Journal of Automation \& Systems Engineering, ,Vol. 8 No.4, December-2014 .

\section{Published By:}


6. Okoro O.T., "Steady state and transient analysis of induction motor driving a pump load", NJT, Vol. 22, No. 1, March 2003.

7. Hari Krishna.Ch, Amarnath.J, Kamakshiah.S, "A simplified SVPWM algorithm for multi-level inverter fed DTC of induction motor drive", IJEIT Vol. 1, Issue 4, April 2012.

8. Manivannam.S, Karuppusamy.P, Veerakumar.S, Nandhakumar.A, "Study and analysis of three phase voltage source inverter fed induction motor drive in various pulse width modulation techniques", IJSET, Vol. 3, Issue 8, pp 1111-1114.

9. Satheesh.G, Sai Baba.Ch, Bramhananda Reddy.T, "Novel SVPWM algorithm for open end winding induction motor drive using the concept of imaginary switching times", International Journal of Applied Science and Technology, Vol. 2, No. 4, 2011.

\section{AUTHORS PROFILE}

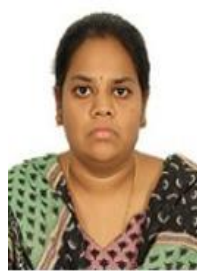

Usha Nadimpalli received her B.E. in Electrical \& Electronics Engineering from Madras University in 2000,and M.Tech in Power Electronics and Drives from JNTU, Hyderabad, India in 2006.She is a member of ISTE. Her study and research interests include Power Electronics, Electric Drives \& Power quality.

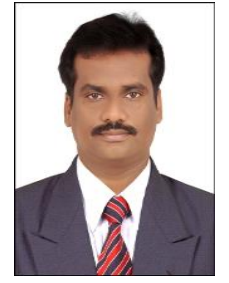

P.V.Prasad, is

currently a professor in the Electrical and Electronics Engineering Department, CBIT, Hyderabad. He received his Ph.D. from JNTUH. He is one of member in the editorial board of International Journal of Mathematical Sciences and Applications (IJMSA). He has authored 2 textbooks and published around 45 papers. His area of interests are Power quality and Power Systems.

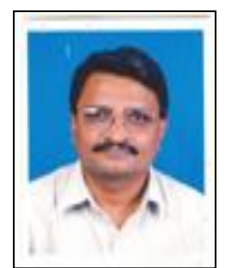

Kolli Ramesh Reddy received B.Tech in Electrical \& Electronics Engineering from NU, in 1985 M.Tech in Electrical Engineering from REC Warangal, in 1989 and Ph.D from Sri Venkateswara University Tirupathi, India in 2004. He is an author of 60 research papers and author of 2 text books. He is an Editorial member of WASET, IE(I), IEEE, \& NAFEN. He is a reviewer for the IEEE Transactions International Journal on Power Delivery and National Journal of kolkata Institution of Engineers . His research and study interests include Multi phase systems and Power quality in power systems. 